\title{
GROWTH AND YIELD STIMULATION OF WINTER OILSEED RAPE (BRASSSICA NAPUS L.) BY MG-TITANIT FERTILISER
}

\author{
PETER KOVÁČIK ${ }^{1 *}$, MICHAELA HAVRLENTOVÁ ${ }^{2,3}$, VLADIMÍR ŠIMANSKÝ1
}

${ }^{1}$ Slovak University of Agriculture in Nitra

${ }^{2}$ National Agricultural and Food Center

${ }^{3}$ University of SS. Cyril and Methodius

KOVÁČIK, P. - HAVRLENTOVÁ, M. - ŠIMANSKÝ, V.: Growth and yield stimulation of winter oilseed rape (Brassica napus L.) by MG-Titanit fertiliser. Agriculture (Polnohospodárstvo), vol. 60, 2014, no. 4, pp. 132-141.

The effort to achieve higher yields at the required qualitative level has led to the intensive studying the problems of the rational usage of the titanium containing fertilisers by the agricultural research in the course the previous thirty years. Therefore, the objective of the experiment was to evaluate the impact of two doses of Mg-Titanit (0.2 1/ha and $0.4 \mathrm{1} / \mathrm{ha}$ ) on the formation of the aboveground and underground phytomass, also on the total chlorophyll in leaves, on the titanium and nitrogen content in the seeds and straw, on the quantity and quality of winter rape yield. The doses were applied two or three times on the leaves of winter rape (BBCH 50-52, $\mathrm{BBCH} 59, \mathrm{BBCH} 66-67)$. The experiment was realized on the Haplic Chernozem $\left(48^{\circ} 42\right.$ N, 17 $7^{\circ} 70^{\prime}$ E - Western Slovakia) during two farming years

Key words: biostimulant, fertiliser, titanium, winter rape

Titanium ranks among ten most frequently occuring elements in the earth crust. In spite of this fact, in most plants the titanium content is low and it varies in the interval $0.1 \mathrm{mg} / \mathrm{kg}-10.0 \mathrm{mg} / \mathrm{kg}$ of dry substance (Tlustoš et al. 2005). The reason for the low content of Ti in plants is its low bioaccessability in both acid and alkaline soils.

In the $20^{\text {th }}$ century it was detected that the titanium usage in the crop production could increase not only the chlorophyll content in the plant leaves but also the content of vitamin $\mathrm{C}$, sugar and nutri-
(2009/2010 and 2010/2011). The results showed that all three applications of Mg-Titanit in both doses stimulated the formation of aboveground and underground phytomass of winter rape. The highest growth of phytomass was detected after the second application. The application of $\mathrm{Mg}$-Titanit in the growth phases $\mathrm{BBCH} 50-52$ and $\mathrm{BBCH}$ 59 increased the contents of both chlorophylls ( $\underline{\mathrm{a}}$ and $\underline{\mathrm{b}}$ ), where the growth of chlorophyll $\underline{b}$ content was more considerable than the growth of chlorophyll a content. The third spraying by $\mathrm{Mg}$-Titanit decreased the content of the total chlorophyll. The application of Mg-Titanit had the positive impact on the yield of seeds, straw and fat content in the winter oilseed rape seeds.

ents in the plants of tomato, grapevine, potato, sugar beet, strawberries and kohlrabi. Titanium can increase the yield of cereals, root crops, oil plants, fruit, vegetables and technical crops, namely from $5 \%$ to $50 \%$ and decrease the content of nitrates and some heavy metals (Traetta-Mosca 1913; Pais 1983; Balík et al. 1989; Tichý \& Tóth 1990; Carvajal et al. 1994; Carvajal \& Alcaraz 1998). Thanks to these findings the detailed research of the titanium impact on plants started (Kužel et al. 2003; Alcaraz-Lopez et al. 2003; Tlustoš et al. 2005). It resulted in the

Prof. Ing. Peter Kováčik, CSc. (*Corresponding author), Slovak University of Agriculture in Nitra, Faculty of Agrobiology and Food Resources, Department of Agrochemistry and Plant Nutrition, Slovak Republic. E-mail: Peter.Kovacik@uniag.sk RNDr. Michaela Havrlentová, PhD., National Agricultural and Food Center/Research Institute of Plant Production Piešt’any, Bratislavská cesta 122, SK-92168 Piešt’any, Slovak Republic; University of SS. Cyril and Methodius, Department of Biotechnology, Námestie J. Herdu 2, SK-91701 Trnava, Slovak Republic

Doc. Ing. Vladimír Šimanský, PhD., Slovak University of Agriculture in Nitra, Faculty of Agrobiology and Food Resources, Department of Soil Science and Geology, Slovak Republic 
information that it is highly assumed the foliar application of titanium to have the negative impact on crops in the soils with the deficient $\mathrm{Mg}$ content and the soils with less than $\mathrm{pH} 6$ and content less than $\mathrm{C}_{\mathrm{ox}} 0.7 \%$. It was found out that the symptoms of the toxic impact of titanium on some plants could be expected in the cases when the titanium concentration in sprays was higher than $10 \mathrm{mg} / \mathrm{kg}$, or $12.5 \mathrm{mg} / 1$ (Kužel et al. 2007). There are less scientific facts about the phytotoxic effects of the foliar application of titanium on plants than the facts about their positive impact. Therefore, the Slovak producers of the liquid fertilisers add titanium into the common microelements (Kováčik 2014).

One of the fertilisers containing titanium is $\mathrm{Mg}$-Titanit, which is being used not only in Slovakia but also in the whole world. In 2013 this fertiliser was reclassified as a biostimulator. In many cases its usage is effective economically, however, its optimal application doses and the optimal application dates have not been determined yet (Dobromilska 2007).
The objective of the paper is to evaluate the impact of two doses of the fertiliser Mg-Titanit ( $0.2 \mathrm{l} / \mathrm{ha}$ and $0.4 \mathrm{l} / \mathrm{ha}$ ), which were applied two or three times on the winter oilseed rape leaves on: dynamics of the underground and aboveground phytomass formation, the content of the total chlorophyll in leaves, the content of titanium and nitrogen in seeds and straw, quantity and quality of winter oilseed rape yield.

\section{MATERIAL AND METHODS}

The effect of the application of liquid fertiliser Mg-Titanit (MgTi) on creation of aboveground and underground phytomass dynamics, total chlorophyll content and yield parameters of winter oilseed rape was investigated in a small plot field trial $\left(20 \mathrm{~m}^{2}\right.$ per one plot) realized on the Haplic Chernozem $\left(48^{\circ} 42^{\prime} \mathrm{N}\right.$, $17^{\circ} 70^{\prime} \mathrm{E}$ - western Slovakia) during two farming years $(2009 / 2010$ and 2010/2011).

$\mathrm{T}$ a

Soil agrochemical parameters before the foundation of experiments in a soil layer $0.0-0.6 \mathrm{~m}$

\begin{tabular}{|c|c|c|c|c|c|c|c|c|c|}
\hline \multirow{2}{*}{ Year } & $\mathrm{N}_{\min }$ & $\mathrm{P}$ & $\mathrm{K}$ & $\mathrm{Ca}$ & $\mathrm{Mg}$ & $\mathrm{S}$ & $\mathrm{N}_{\mathrm{t}}$ & \multirow{2}{*}{$\frac{\mathrm{C}_{\mathrm{ox}}}{[\%]}$} & \multirow{2}{*}{$\mathrm{pH}_{\mathrm{KCl}}$} \\
\hline & \multicolumn{7}{|c|}{$[\mathrm{mg} / \mathrm{kg}]$} & & \\
\hline $2009 / 2010$ & 12.05 & 40 & 221 & 3,575 & 414 & 15.0 & 1,709 & 1.49 & 6.89 \\
\hline 2010/2011 & 13.05 & 23 & 160 & 7,650 & 505 & 34.5 & 1,099 & 1.25 & 6.95 \\
\hline
\end{tabular}

Nmin - inorganic nitrogen; P, K, Ca, Mg - available phosphorous, potassium, calcium, magnesium; S - water soluble sulphur, $\mathrm{Nt}-$ total nitrogen, Cox - total (oxidizable) carbon

$\mathrm{T}$ a

Variants of experiment

\begin{tabular}{|c|c|c|c|c|}
\hline \multirow{2}{*}{ Variant } & \multicolumn{2}{|c|}{ Growth phase of Mg-Titanit application } \\
\cline { 3 - 5 } & designation & BBCH 50-52 & BBCH 59 & BBCH 66-67 \\
\hline number & 0 & 0 & \multicolumn{2}{|c|}{ dosage [1/ha] } \\
\hline 1 & $2 \times$ Ti0.2 & 0.2 & 0.2 & 0 \\
3 & $3 \times$ Ti0.2 & 0.2 & 0.2 & 0.2 \\
4 & $2 \times$ Ti0.4 & 0.4 & 0.4 & 0 \\
5 & $3 \times$ Ti0.4 & 0.4 & 0.4 & 0.4 \\
\hline
\end{tabular}


The agrochemical parameters of Haplic Chernozem taken from soil layer $0.0 \mathrm{~m}-0.6 \mathrm{~m}$ are given in Table 1 . The agrochemical parameters were determined by the following methods: $\mathrm{N}_{\min }=\mathrm{N}-\mathrm{NH}_{4}^{+}+\mathrm{N}^{-} \mathrm{NO}_{3}^{-}, \mathrm{N}_{-} \mathrm{NH}_{4}^{+}-$colorimer-

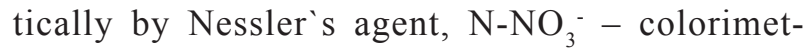
rically by the phenol 2.4 disulphonic acid, P - colorimetrically (Mehlich III - Mehlich 1984), $\mathrm{K}$ and $\mathrm{Ca}$ - flame photometry (Mehlich III Mehlich 1984), Mg - AAS (Mehlich III - Mehlich 1984), S - spectrometrically ICP OES (Zbíral 2002), $\mathrm{C}_{\mathrm{ox}}$ - oxidometrically by Ťjurin in modification of Nikitin (Dziadowiec \& Gonet 1999), $\mathrm{N}_{\mathrm{t}}$ - by distilling (Kjeldahl - Bremner 1960), $\mathrm{pH} / \mathrm{KCl}$ - potentiometrically $\left(1.0 \mathrm{~mol} / \mathrm{dm}^{3} \mathrm{KCl}\right)$. Experiment consisted of 5 variants (var. 0; $2 \times \operatorname{Ti} 0.2 ; 3 \times \operatorname{Ti} 0.2 ; 2 \times \operatorname{Ti} 0.4 ; 3 \times \operatorname{Ti0} .4)$. 0 - control treatment without MgTi fertiliser; $2 \times \mathrm{Ti} 0.2$ two applications of MgTi in the dose of $0.21 / \mathrm{ha}$; $3 \times \mathrm{Ti0} .2$ - three applications of MgTi in the dose of $0.2 \mathrm{l} / \mathrm{ha} ; 2 \times \mathrm{Ti} 0.4$ - two applications of MgTi in the dose of $0.41 / \mathrm{ha} ; 3 \times \mathrm{Ti0} 0.4$ - three applications of MgTi in the dose of 0.4 1/ha. The fertiliser was applied in the spring during two, or three different growth stages: $\mathrm{BBCH} 50-52, \mathrm{BBCH} 59, \mathrm{BBCH}$ 66-67 (Table 2). The plant sampling was carried out two or three weeks after spraying by the fertiliser. Growth phase (BBCH 59, BBCH 66-67, $\mathrm{BBCH} 71$ ) in which plant samples were taken for study of aboveground phytomass creation is given in Table 3. To determine the content of the assimilation pigments (chlorophyll $\underline{a}$, chlorophyll $\underline{b}$ and total chlorophyll) the last developed leaf of ten plants was sampled. The pigments were determined by spectrophotometric method (Lichtenthaler 1987).
The fat content in seeds was detected by Soxhlet method and nitrogen content in seeds was detected by Eastin (1978) method. To determine the Ti content in seeds was used the inductively coupled plasma atomic emission spectroscopy (ICP-AES) method (Zbíral et al. 2011). Obtained results were processed by mathematical and statistical method, by analysis of variance (ANOVA) and linear regression analysis using Statgraphics PC software, version 5.0.

Mg-Titanit fertiliser (stimulant) is dark brown liquid with bulk density $1.36 \mathrm{~kg} / \mathrm{l}$. It contains 8.5 $\mathrm{g}$ of titanium per 1 liter of fertiliser, $3 \%$ of magnesium, and $4 \%$ of sulfur. Titanium is in form of titanium ascorbate and sulfur with magnesium is in form of magnesium sulphate $\left(\mathrm{MgSO}_{4}\right)$.

\section{RESULTS AND DISCUSSION}

The data presented in the Tables 4 and 5 show that the Mg-Titanit application carried out in the growth phase $\mathrm{BBCH}$ 50-52 stimulated the formation of the aboveground and underground phytomass of winter oilseed rape. The impact on the aboveground and underground parts was comparable. The growth of the aboveground phytomass varied in the interval from 11.5 to $28.47 \%$ and the weight gain of roots varied in the interval from 15.35 to $26.77 \%$. A higher single dose of Mg-Titanit (0.4 1/ha) stimulated more significantly the formation of the rape phytomass than a lower dose of $(0.2 \mathrm{l} / \mathrm{ha}) \mathrm{Mg}$-Titanit.

After the repeated, second application of Mg-Titanit the differences between the weight of phytomass, created in the variants treated by $\mathrm{Mg}$-Titanit (var. 2-5), and the untreated variant (var. 1) were

T $\begin{array}{llllllllll}1 & \text { b } & 1 & \text { e } & 3\end{array}$

Growth stages of sampling of winter oilseed rape plant and spraying stimulator Mg-Titanit

\begin{tabular}{|c|c|c|c|}
\hline \multicolumn{4}{|c|}{ Type of treatment } \\
\hline $1^{\text {st }}$ Ti spray & $\begin{array}{c}1^{\text {st }} \text { sampling } \\
\text { and subsequent } \\
2^{\text {nd }} \text { Ti spray }\end{array}$ & $\begin{array}{c}2^{\text {nd }} \text { sampling } \\
\text { and subsequent } \\
3^{\text {nd }} \text { Ti spray }\end{array}$ & $3^{\text {rd }}$ sampling \\
\hline \multicolumn{4}{|c|}{ Growth phase } \\
\hline $\begin{array}{l}\text { Occurrence of the inflorescence - } \\
\text { inflorescence BBCH 50-52 }\end{array}$ & $\begin{array}{l}\text { yellow bud } \\
\text { BBCH } 59\end{array}$ & $\begin{array}{c}\text { flowering } \\
\text { BBCH 66-67 }\end{array}$ & $\begin{array}{l}\text { end of flowering } \\
\text { BBCH } 71\end{array}$ \\
\hline
\end{tabular}


even more significant. A lower dose of Mg-Titanit (var. 2 and 3) had more positive impact on the formation of the aboveground phytomass than a higher dose (var. 4 and 5 - Table 4). On the contrary, the root formation was increased with the growth of the application dose of Mg-Titanit, similarly to the first spraying.

The third spraying did not influence statistically significantly the formation of phytomass. Its effect on the formation of the abo- veground and underground phytomass was slightly positive, in particular, it had more positive impact on roots (cca $5.0 \%$ increase) than on the aboveground part (cca from 1.5$3.0 \%$ increase). The different conclusion was achieved by Kováčik et al. (2014), the third spraying by $\mathrm{Mg}$-Titanit, which was used in the growth phase $\mathrm{BBCH} 55$, inhibited the formation of the aboveground wheat phytomass.

T a

The effects of the dose and the date of application of Mg-Titanit on the dynamic creation of aboveground phytomass ( $100 \%$ dry matter) of winter oilseed rape (mean of two years)

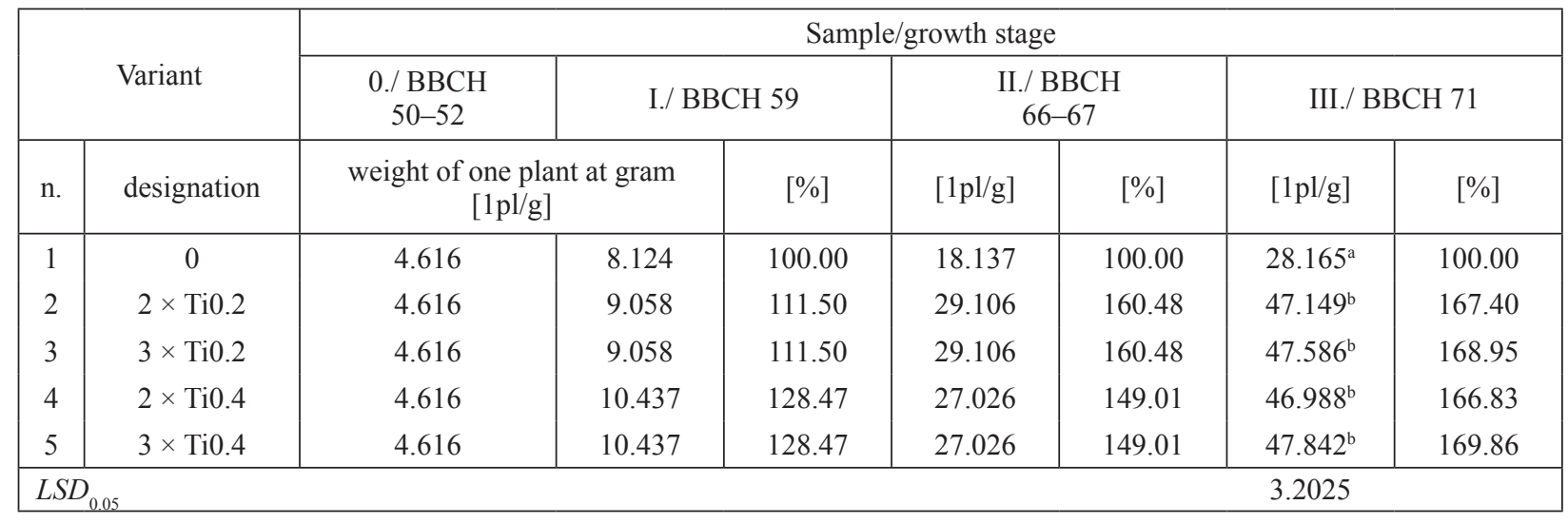

n. - number, $1 \mathrm{pl} / \mathrm{g}$ - weight of one plant at gram, $L S D_{0.05}-$ least significant difference at the level $\alpha=0.05$ ( $L S D$ test), different letter behind a numerical value respond to the statistically significant difference at the level $95.0 \%$

T a b $\quad 1$ e 5

The effects of the dose and the date of application of Mg-Titanit on the dynamic creation of underground phytomass ( $100 \%$ dry matter) of winter oilseed rape (mean of two years)

\begin{tabular}{|c|c|c|c|c|c|c|c|c|}
\hline \multirow{2}{*}{ Variant } & \multirow{2}{*}{ Variant } & \multicolumn{7}{|c|}{ Sample/growth stage } \\
\hline & & $0 . / \mathrm{BBCH} 50-52$ & \multicolumn{2}{|c|}{ I./ BBCH 59} & \multicolumn{2}{|c|}{ II./ BBCH $66-67$} & \multicolumn{2}{|c|}{ III./ BBCH 71} \\
\hline $\mathrm{n}$. & designation & \multicolumn{2}{|c|}{$[1 \mathrm{pl} / \mathrm{g}]$} & {$[\%]$} & {$[1 \mathrm{pl} / \mathrm{g}]$} & {$[\%]$} & {$[1 \mathrm{pl} / \mathrm{g}]$} & {$[\%]$} \\
\hline 1 & 0 & 2.109 & 3.022 & 100.00 & 3.539 & 100.00 & $4.525^{\mathrm{a}}$ & 100.00 \\
\hline 2 & $2 \times \mathrm{Ti} 0.2$ & 2.109 & 3.486 & 115.35 & 5.141 & 145.27 & $6.215^{\mathrm{b}}$ & 137.35 \\
\hline 3 & $3 \times \mathrm{Ti} 0.2$ & 2.109 & 3.486 & 115.35 & 5.141 & 145.27 & $6.440^{\mathrm{b}}$ & 142.32 \\
\hline 4 & $2 \times \mathrm{Ti} 0.4$ & 2.109 & 3.831 & 126.77 & 5.459 & 154.25 & $6.135^{\mathrm{b}}$ & 135.58 \\
\hline 5 & $3 \times \mathrm{Ti} 0.4$ & 2.109 & 3.831 & 126.77 & 5.459 & 154.25 & $6.359^{\mathrm{b}}$ & 140.53 \\
\hline \multicolumn{2}{|c|}{$L S D_{0.05}$} & & & & & \multicolumn{3}{|c|}{0.5520} \\
\hline
\end{tabular}

n. - number, $1 \mathrm{pl} / \mathrm{g}$ - weight of one plant at gram, $L S D_{0.05}$ - limit of significant difference at the level $\alpha=0.05$ ( $L S D$ test), different letter behind a numerical value respond to the statistically significant difference at the level $95.0 \%$ 
A bigger aboveground and underground phytomass was formed in the variants with three sprayings (var. 3 and 5), in comparison with the variants of two sprayings (var. 2 and 4 - Table 6).

In all samplings, the positive impact of the fertiliser (biostimulator) Mg-Titanit on the formation of winter oilseed rape phytomass was recorded, which corresponds with the results of several authors (Matuškovič 1995; Dobromilská 2007) about the impact of fertilisers containing titanium on the plant phytomass.
As there are numerous elements of the mineral plant nutrition, their effect on the chlorophyll formation is different. There is usually monitored the positive correlation between the content of nitrogen, magnesium and sulphur in a plant and the content of total chlorophyll in a plant (Marschner 2005; Tůma \& Tůmová 2006). The higher chlorophyll content on a leaf surface unit was recorded also as a result of the insufficient nutrition by phosphorus (Kováčik 2014). The decrease of the chlorophyll content is

T a b 1 e 6

The impact of two and three appplications of Mg-Titanit on the weight of winter oilseed rape phytomass in the growth phase $\mathrm{BBCH} 71$, regardless the application dose

\begin{tabular}{|c|c|c|c|c|c|}
\hline \multicolumn{2}{|c|}{ Variant } & \multicolumn{2}{c|}{ Aboveground phytomass } & \multicolumn{2}{c|}{ Underground phytomass } \\
\hline number & designation & {$[1 \mathrm{pl} / \mathrm{g}]$} & {$[\%]$} & {$[1 \mathrm{pl} / \mathrm{g}]$} & {$[\%]$} \\
\hline 1 & 0 & 28.165 & 100.00 & 4.525 & 100.00 \\
2 and 4 & $2 \mathrm{Ti}$ & 47.069 & 167.12 & 6.175 & 136.46 \\
3 and 5 & $3 \mathrm{Ti}$ & 47.714 & 169.41 & 6.400 & 141.44 \\
\hline
\end{tabular}

$2 \mathrm{Ti}$ - two appplications of Mg-Titanit, 3 Ti - three appplications of Mg-Titanit

T a b 1 e 7

Impact of trial treatments on dynamics of changes of pigment contents in leaves of winter oilseed rape (mean of two years)

\begin{tabular}{|c|c|c|c|c|c|c|c|}
\hline \multicolumn{2}{|c|}{ Variant } & \multirow{2}{*}{$\begin{array}{l}\text { Growth } \\
\text { stage }\end{array}$} & Chlorophyll $\underline{a}$ & Chlorophyll $\underline{b}$ & Chlorophyll $\underline{a} / \underline{b}$ & \multicolumn{2}{|c|}{ Chlorophyll $\underline{a}+\underline{b}$} \\
\hline number & designation & & \multicolumn{2}{|c|}{$\left[\mathrm{mg} / \mathrm{m}^{2}\right]$} & & {$\left[\mathrm{mg} / \mathrm{m}^{2}\right]$} & {$[\%]$} \\
\hline 1 & 0 & \multirow{3}{*}{$\begin{array}{c}\mathrm{BBCH} \\
59\end{array}$} & $335.668^{\mathrm{a}}$ & $132.781^{\mathrm{a}}$ & 2.528 & $468,449^{\mathrm{a}}$ & 100,00 \\
\hline $2-3$ & $\mathrm{Ti} 0.2$ & & $349.496^{\mathrm{a}}$ & $146.293^{b}$ & 2.389 & $495.789^{b}$ & 105.84 \\
\hline $4-5$ & Ti0.4 & & $339.616^{\mathrm{a}}$ & $143.783^{\mathrm{b}}$ & 2.362 & $483.399^{\mathrm{ab}}$ & 103.19 \\
\hline \multicolumn{3}{|l|}{$L S D_{0.05}$} & 15.364 & 10.474 & - & 18.879 & - \\
\hline 1 & 0 & \multirow{3}{*}{$\begin{array}{l}\mathrm{BBCH} \\
66-67\end{array}$} & $347.716^{\mathrm{a}}$ & $145.854^{\mathrm{a}}$ & 2.384 & $493.570^{\mathrm{a}}$ & 100.00 \\
\hline $2-3$ & $\mathrm{Ti} 0.2$ & & $360.477^{b}$ & $164.003^{b}$ & 2.198 & $524.480^{\mathrm{b}}$ & 106.26 \\
\hline $4-5$ & $\mathrm{Ti0} 0.4$ & & $350.964^{\mathrm{ab}}$ & $162.935^{\mathrm{b}}$ & 2.154 & $513.899^{b}$ & 104.12 \\
\hline \multicolumn{3}{|l|}{$L S D_{0.05}$} & 10.404 & 6.884 & - & 11.684 & - \\
\hline 1 & 0 & \multirow{5}{*}{$\begin{array}{c}\mathrm{BBCH} \\
71\end{array}$} & $327.814^{\mathrm{a}}$ & $145.436^{\mathrm{a}}$ & 2.254 & $473.250^{\mathrm{a}}$ & 100.00 \\
\hline 2 & $2 \times \mathrm{Ti} 0.2$ & & $357.448^{c}$ & $165.792^{\mathrm{b}}$ & 2.156 & $523.240^{c}$ & 110.56 \\
\hline 3 & $3 \times \mathrm{Ti} 0.2$ & & $337.746^{\mathrm{ab}}$ & $158.864^{\mathrm{b}}$ & 2.126 & $496.610^{\mathrm{b}}$ & 104.94 \\
\hline 4 & $2 \times \mathrm{Ti} 0.4$ & & $347.546^{\mathrm{bc}}$ & $163.014^{\mathrm{b}}$ & 2.132 & $510.560^{\mathrm{bc}}$ & 107.88 \\
\hline 5 & $3 \times \mathrm{Ti} 0.4$ & & $334.974^{\mathrm{ab}}$ & $158.156^{\mathrm{b}}$ & 2.118 & $493.130^{\mathrm{b}}$ & 104.20 \\
\hline \multicolumn{3}{|l|}{$L S D_{0.05}$} & 19.223 & 12.357 & - & 19.718 & - \\
\hline
\end{tabular}

$L S D_{0.05}$ - least significant difference at the level $\alpha=0.05$ ( $L S D$ test), different letter behind a numerical value respond to the statistically significant difference at the level $95.0 \%$ 
caused by the excessive plant nutrition by microelements and titanium (Hrubý et al. 2002), or growing crop in the soils with a higher content of heavy metals (Ducsay 2011), or growing crop in the polluted environment (Bergman 1992).

The data in the Table 7 show that in each sampling the content of pigments (chlorohyll $\underline{a}$, chlorophyll $\underline{b}$ and subsequently total chlorophyll) was higher in the variants treated by Mg-Titanit than in the control, untreated variant. The first and partially also the second spraying (application in the growth phases $\mathrm{BBCH} 50-52$ and $\mathrm{BBCH} 59$, and measurement in phases BBCH 59 and $\mathrm{BBCH}$ 66-67) had more significant impact on the growth of chlorophyll $\underline{b}$ than the growth of chlorophyll $\underline{a}$. Similarly, Kováčik et al. (2014) monitored a higher increase of chlorophyll $\underline{b}$ content in the wheat leaves than chlorophyll $\underline{b}$ after several applications of Mg-Titanit. On the contrary, after the autumn application of the pig manure on maize and sunflower Kováčik (2014)

T a

The impact of Mg-Titanit application on nitrogen and titanium content in winter oilseed rape seed and straw (mean of two years)

\begin{tabular}{|c|c|c|c|c|c|c|c|c|c|}
\hline \multicolumn{2}{|c|}{ Variant } & \multicolumn{2}{c|}{$\mathrm{N}$ in seeds } & \multicolumn{2}{c|}{$\mathrm{N}$ in straw } & \multicolumn{2}{c|}{ Ti in seeds } & \multicolumn{2}{c|}{ Ti in straw } \\
\hline $\mathrm{n}$. & designation & {$[\mathrm{mg} / \mathrm{kg}]$} & {$[\%]$} & {$[\mathrm{mg} / \mathrm{kg}]$} & {$[\%]$} & {$[\mathrm{mg} / \mathrm{kg}]$} & {$[\%]$} & {$[\mathrm{mg} / \mathrm{kg}]$} & {$[\%]$} \\
\hline 1 & 0 & $33,347^{\mathrm{a}}$ & 100.00 & $7,840^{\mathrm{b}}$ & 100.00 & $1.34^{\mathrm{a}}$ & 100.00 & $8.40 \mathrm{a}$ & 100.00 \\
2 & $2 \times \mathrm{Ti0} 0$ & $33,587^{\mathrm{ab}}$ & 100.72 & $7,654^{\mathrm{ab}}$ & 97.63 & $1.50^{\mathrm{a}}$ & 111.94 & $10.40 \mathrm{~b}$ & 123.81 \\
3 & $3 \times \mathrm{Ti0} 0$ & $33,818^{\mathrm{abc}}$ & 101.41 & $7,576^{\mathrm{ab}}$ & 96.63 & $1.77^{\mathrm{b}}$ & 132.09 & $11.32 \mathrm{c}$ & 134.76 \\
4 & $2 \times \mathrm{Ti0} 0$ & $33,944^{\mathrm{bc}}$ & 101.79 & $7,502^{\mathrm{a}}$ & 95.69 & $2.08^{\mathrm{c}}$ & 155.22 & $10.78 \mathrm{bc}$ & 128.33 \\
5 & $3 \times \mathrm{Ti0.4}$ & $34,299^{\mathrm{c}}$ & 102.85 & $7,536^{\mathrm{a}}$ & 96.12 & $2.30^{\mathrm{c}}$ & 171.64 & $10.98 \mathrm{bc}$ & 130.71 \\
\hline mean & 33,799 & - & 7621.6 & - & 1.798 & - & 10.376 & - & \\
$L S D_{0.05}$ & 531.562 & - & 290.241 & - & 0.224 & - & 0.724 & - & \\
\hline
\end{tabular}

n. - number, $L S D 0.05$ - least significant difference at the level $\alpha=0.05$ (LSD test), different letter behind a numerical value respond to the statistically significant difference at the level $95.0 \%$

T

The influence of application Mg-Titanit on the some yield parameters of winter oilseed rape seeds

\begin{tabular}{|c|c|c|c|c|c|c|c|c|}
\hline \multirow{2}{*}{\multicolumn{2}{|c|}{ Variant }} & \multicolumn{3}{|c|}{ Yield (seeds) } & \multirow{3}{*}{$\begin{array}{l}\text { Seeds/straw } \\
\quad(\text { mean })\end{array}$} & Oil & Yield of oil & TKW \\
\hline & & 2010 & 2011 & mean & & \multicolumn{3}{|c|}{ mean of two years } \\
\hline $\mathrm{n}$. & designation & \multicolumn{3}{|c|}{$[\mathrm{t} / \mathrm{ha}]$} & & {$[\%]$} & [t/ha] & {$[\%]$} \\
\hline 1 & 0 & $2.83^{\mathrm{a}}$ & $4.69^{\mathrm{a}}$ & $3.76^{\mathrm{a}}$ & 0.60 & $40.94^{\mathrm{a}}$ & $1.54^{\mathrm{a}}$ & $4.78^{\mathrm{a}}$ \\
\hline 2 & $2 \times \mathrm{Ti} 0.2$ & $3.20^{\mathrm{b}}$ & $5.22^{\mathrm{b}}$ & $4.21^{\mathrm{b}}$ & 0.65 & $41.72^{\mathrm{b}}$ & $1.76^{\mathrm{b}}$ & $4.75^{\mathrm{a}}$ \\
\hline 3 & $3 \times \mathrm{Ti} 0.2$ & $3.00^{\mathrm{ab}}$ & $5.87^{\mathrm{c}}$ & $4.44^{\mathrm{b}}$ & 0.70 & $41.90^{\mathrm{b}}$ & $1.86^{\mathrm{b}}$ & $4.73^{\mathrm{a}}$ \\
\hline 4 & $2 \times \mathrm{Ti} 0.4$ & $3.20^{\mathrm{b}}$ & $5.23^{\mathrm{b}}$ & $4.21^{\mathrm{b}}$ & 0.67 & $42.15^{\mathrm{b}}$ & $1.77^{\mathrm{b}}$ & $4.72^{\mathrm{a}}$ \\
\hline 5 & $3 \times \mathrm{Ti} 0.4$ & $3.06^{\mathrm{ab}}$ & $5.63^{\mathrm{c}}$ & $4.34^{\mathrm{b}}$ & 0.68 & $41.65^{\mathrm{b}}$ & $1.81^{\mathrm{b}}$ & $4.72^{\mathrm{a}}$ \\
\hline \multicolumn{2}{|r|}{ mean } & 3.058 & 5.328 & 4.192 & 0.66 & 41.672 & 1.748 & 4.74 \\
\hline \multicolumn{2}{|r|}{$L S D_{0.05}$} & 0.240 & 0.275 & 0.274 & - & 0.669 & 0.218 & 0.0631 \\
\hline
\end{tabular}

n. - number, $L S D_{0.05}$ - least significant difference at the level a $=0.05$ ( $L S D$ test), different letter behind a numerical value respond to the statistically significant difference at the level $95.0 \%$ 
recorded higher increase of chlorophyll $\underline{a}$ than chlorophyll $\underline{b}$ in the leaves of those crops. The author explained this fact by the significant content of nitrogen and other macroelements (magnesium, phosphorus, sulphur, potassium and calcium) in manure.

After the first and second spraying by Mg-Titanit there was the highest content of both pigments recorded in the variants 2 and 3 , i. e. in the variants where the tested fertiliser was applied in the single doses at the level $0.2 \mathrm{l} / \mathrm{ha}$. After the first spraying the content of total chlorophyll was increased by $5.84 \%$ and after the second spraying by $6.26 \%$. In the variants 4 and 5, where Mg-Titanit was applied in the single doses of $0.4 \mathrm{l} / \mathrm{ha}$, the contents were lower insignificantly than in the variants 2 and 3, however, they were higher than in the control variant. It is evident that from the aspect of chlorophyll formation in the leaves of winter oilseed rape that it is more suitable if the Mg-Titanit is applied in the single doses of $0.2 \mathrm{l} / \mathrm{ha}$ than in the doses of $0.4 \mathrm{l} / \mathrm{ha}$.

The third spraying by Mg-Titanit (BBCH 66-67, measurement $\mathrm{BBCH} 71$ ) caused the decrease of the total chlorophyll content, which corresponds with some the data of Kováčik (2014). He claim that in $65 \%$ cases there is the negative impact of spraying by Mg-Titanit on the contents of the total chlorophylls in the wheat leaves if the spraying is carried out before the wheat ear formation. He recorded the growth of the total chlorophyll content in 35\%.

After three sprayings by $\mathrm{Mg}$-Titanit $(\mathrm{BBCH}$ 50-52, BBCH 59, BBCH 66-67) there was monitored the decrease of ratio between the chlorophyll $\underline{a}$ and chlorophyll $\underline{b}$. This ratio between the chlorophyll $\underline{a}$ and $\underline{b}$ was also diminished in the following days of the growing season. It seemed that the older plant was - the less the ratio was. However, in the period $\mathrm{BBCH} 50$ to 67 the rape phytomass grows fast which results in analysing still (relatively) younger leaves. Therefore, the obtained data are not in contrast with the data given by Ebbs and Uchil (2008). They claim that in the process of the plant senescence there the transformation from chlorophyll $\underline{b}$ to chlorophyll $\underline{a}$ occurs and also there is the increased ratio of chlorophyll $\underline{a}$ to chlorophyll $\underline{b}$.

The nitrogen content in the rape seeds was increased with the growth of the total application dose of Mg-Titanit (Table 8). The total doses of Mg-Titanit 0.4 and $0.61 /$ ha (var. 2 and 3 ) increased the nitrogen content insignificantly and the doses 0.8 and $1.2 \mathrm{l} /$ ha increased the content significantly (var. 4 and 5).

The impact of Mg-Titanit on straw was different. In all the variants treated by Mg-Titanit there was the nitrogen content lower in comparison with the control, unfertilised variant. The lowest content was evident in the variants of the highest total application dose of Mg-Titanit (var. 4 and 5). These facts show that Mg-Titanit had impact on the redistribution of nitrogen between the vegetative and generative aboveground phytomass in favour of the generative phytomass.

The data related to the titanium content in plants are rare (Lopez-Moreno et al. 1996; Tlustoš et al. 2005). In the submitted experiment the titanium content in the rape seeds varied in the interval from 1.34 to $2.3 \mathrm{mg} / \mathrm{kg}$ and in straw from 8.4 to $11.32 \mathrm{mg} / \mathrm{kg}$ on average in the course of two years, which corresponds with the data achieved by the above mentioned authors (Table 8 ). The quantity of titanium in the rape seed was increased proportionally with the growing application dose of the fertiliser or with the growing nitrogen content in the rape seed. The highest content was found out in the variant 5 where $1.2 \mathrm{l} / \mathrm{ha}$ of Mg-Titanit was applied totally.

The titanium content in the rape straw was higher in all variants fertilised by Mg-Titanit comparing to the unfertilised variant. Unlike seeds the titanium content in straw did not increase proportionally with a higher dose of $\mathrm{Mg}$-Titanit. The highest quantity of titanium was present in the variants where $\mathrm{Mg}$-Titanit was applied three times (var. 3 and 5). The correlation coefficient $r$ at the level of $0.690^{++}$detected between the titanium content in straw and rape seed proved the well-known fact that the increased nutrition by any element results in the increased content of the particular element, however disproportionally, in all organs.

In the rape straw there was 5.77 times more titanium than in the seeds (10.376:1.798), which corresponds with the data presented by Ercoli et al. (2008). They claim there is 4 times less titanium in seeds than in stalks and 7 times less than in maize leaves.

The Table 9 shows that the rape yield was determined by the cultivating year. In the first year the average yield of rape seed was $3.06 \mathrm{t} / \mathrm{ha}$ and in the second year $5.33 \mathrm{t} / \mathrm{ha}$, which means the difference of 
$74 \%$. In spite of the significant impact of the cultivating year on the rape seed yield it is obvious that in both years the lowest seed yield was recorded as significant statistically in the variant where Mg-Titanit was not used (var.1). In the first year of the experiment significantly higher yields were achieved in the variants where Mg-Titanit was applied twice (var. 2 and 4). In this year there was extraordinary humidity $(163.8 \mathrm{~mm})$ during the third application of Mg-Titanit (in May) which probably decreased the effect of the third application. On the contrary, in the second year of the experiment the highest yields were achieved in the variants where Mg-Titanit was used three times. In this year in May there was the normal precipitation $(51.8 \mathrm{~mm})$, which allowed a better usage of the third dose of Mg-Titanit.

On average the differences between the variants fertilised by $\mathrm{Mg}$-Titanit were insignificant in both years of the experiment. However, the highest yields were achieved in the variants 3 and 5 , i. e. in the variants where Mg-Titanit was used three times.

The utilization of Mg-Titanit determined more significantly the yield of rape seed than the yield of rape straw. This fact is the consequence of the changes of proportions between the seed weight and rape weight (Table 9). The least ratio was in the control, unfertilised by Mg-Titanit variant. The application not only had the positive impact on the quantity of seed and straw yield but it also had the positive impact on the fat content in the rape seeds. Apart from the last variant, the growth of the application dose of Mg-Titanit increased the fat content. In all variants fertlised by Mg-Titanit there was the fat content higher significantly in comparison with the control variant. The highest fat content was achieved in the regressing succession in the variants where totally $0.8 \mathrm{l} / \mathrm{ha}, 0.6 \mathrm{l} / \mathrm{ha}, 0.4 \mathrm{l} / \mathrm{ha}$ and $1.2 \mathrm{l} / \mathrm{ha}$ of Mg-Titanit were applied. The differences in the fat content between the variants fertilised by Mg-Titanit were insignificant. Similarly, the differences in the fat production between the variants fertilised by Mg-Titanit were insignificant. The lowest fat production per hectare was detected in the control variant 1.

The fertilising by Mg-Titanit did not have impact on the thousand kernel weight (TKW) significantly. TKW was decreased along with the growth of the application dose of Mg-Titanit. The decrease varied in the interval from $0.63 \%$ to $1.26 \%$, which is the insignificant drop.

The recorded information from the experiment which is related to the present positive impact of the fertiliser Mg-Titanit on the quantity and quality of yield (fat content) ranks among the group of the data ocurring only with the probability of $15 \%$. In other cases $(85 \%)$ the fertilisers stimulating the phytomass growth decrease the fat content in seeds (Kováčik 2014).

The growers' successfulness is determined significantly by their ability to utilize the newest knowledge from all fields of the crop production, including crop nutrition. In order to optimize the crop nutrition the experts look for the dependence between a plant height, stalk thickness or the chlorophyll contents detected in the particular growth phases, and the quantity and quality of the cultivated crops (Kováčik et al. 2011; Kováčik 2014). The data presented in the Table 10 show that there is the highly evidential correlation coefficient between the quantity of rape

T a b 1 e 10

The correlation coefficient $\mathrm{r}$ expressing the correlation between winter oilseed rape seed yield and phytomass or the content of the total chlorophyll in the growth phase $\mathrm{BBCH} 71$

\begin{tabular}{|c|c|c|c|c|}
\hline \multicolumn{2}{|r|}{ Parameter } & \multirow{2}{*}{$\mathrm{r}$} & \multirow{2}{*}{$P$-value } & \multirow{2}{*}{ Symbol } \\
\hline Dependent & Independent & & & \\
\hline \multirow{3}{*}{ Seed yield } & Weight of aboveground phytomass & 0.8994 & $<0.001$ & ++ \\
\hline & Weight of underground phytomass & 0.8902 & $<0.001$ & ++ \\
\hline & Total chlorophyll & 0.5176 & 0.048 & + \\
\hline
\end{tabular}

$P$ values lower than 0.05 indicates conclusiveness and smaller than 0.01 indicates strong conclusiveness 
seed yield and the underground and aboveground phytomass formed in the growth phase BBCH 71 . There the correlation coefficient between the rape seed yield and the chlorophyll content was only evidentiary, i.e. at the threshold of the conclusive evidence. These facts refer to the fact that it is possible to use the information about the formed aboveground or underground phytomass or the chlorophyll content for the purpose of the winter oilseed rape yield prediction. There the precision of prediction will be probably higher if the information about the formed phytomass is used as the information about the total chlorophyll content in the leaves in the growth phase BBCH 71.

\section{CONCLUSION}

All three applications of Mg-Titanit in both single application doses $(0.2 \mathrm{l} / \mathrm{ha}$ and $0.4 \mathrm{l} / \mathrm{ha})$ carried out in the growth phases $\mathrm{BBCH} 50-52, \mathrm{BBCH} 59$, and BBCH 66-67 stimulated the formation of the aboveground and underground phytomass of winter oilseed rape. The first and second application of Mg-Titanit increased the contents of both chlorophylls ( $\underline{a}$ and $\underline{b}$ ). The third spraying by Mg-Titanit decreased the content of the total chlorophyll. The nitrogen and titanium contents in the rape seed were increased along with the growth of the total application dose of Mg-Titanit. The used of Mg-Titanit had the positive impact on the quantity of seed and straw yield as well as the fat content in seeds of rape. The highest seed yields and the highest fat production per hectare were achieved in the variants where $\mathrm{Mg}$-Titanit was used three times. In order to assess the quantity of winter rape yield in the growth phase $\mathrm{BBCH} 71$ it is more suitable to evaluate weight of the formed phytomass (aboveground or underground) than the chlorophyll content in the lastly developed rape leaf.

Acknowledgement. This paper was supported by VEGA project 1/0591/13.

\section{REFERENCES}

ALCARAZ-LÓPEZ, C. - BOTÍA, M. - ALCARAZ, C.F. - RIQUELME, F. 2003. Effects of foliar sprays containing calcium, magnesium and titanium on plum (Prunus domestica L.) fruit quality. In Journal of Plant Physiology, vol. 160, pp. 1441-1446. DOI: 10.1078/0176-1617-00999.

BALÍK, J. - VOSTAL, J. - TLUSTOŠ, P. 1989. Výsledky s ověrováním př́ípravku TITAVIN u vybranych plodin [Results of Titavin tests for chosen crops]. In Sborník VŠZ, Praha, ̌̌ada A, 50, 143-155.

BERGMANN, W. 1992. Nutritional disorders of plants: visual and analytical diagnosis. Jena: Gustav Fischer Verlag, 386 pp. ISBN 3-334-60423-3.

BREMNER, J.M. 1960. Determination of nitrogen in soil by the Kjeldahl method. In Journal of Agricultural Science, vol. 55, no. 1, pp. 11-33.

CARVAJAL, M.F. - MARTÍNEZ-SÁNCHEZ, F. - ALCARAZ, C.F. 1994. Effect of Ti(IV) on some physiological activity indicators of Capsicum annuum L. plants. In Journal of Horticultural Science, vol. 69, pp. 427-432.

CARVAJAL, M. - ALCARAZ, C.F. 1998. Why titanium is a beneficial element for plants. In Journal of Plant Nutrition, vol. 21, pp. 655-664.

DOBROMILSKA, R. 2007. Wplyw stosowania Tytanitu na wzrost pomidora drobnoowocowego [The influence of tytanit treatment on the growth and yield of small-sized tomatoes]. In Roczniki Akademii Rolniczej w Poznaniu CCCLXXXIII, vol. 41, pp. 451-454.

DUCSAY, L. 2011. Obsah chlorofylu, kadmia a zinku v listoch slnečnice v podmienkach $\mathrm{Cd}$ a $\mathrm{Zn}$ stresu [The chlorophyll, cadmium and zinc contents in sunflower leaves under cadmium and zinc stress conditions]. In Chemické Listy, vol. 105, pp. 269-272.

DZIADOWIEC, H. - GONET, S.S. 1999. Przewodnik metodycznydo badań materii organicznej gleb [Methodical guide-book for soil organic matter studies]. Prace Komisji Naukowych Polskiego Towarzystwa Gleboznawczego,N. 120, Komisja chemii gleb, Zespół Materii Organicznej Gleb, N II/16, 65 p.

HRUBÝ, M. - CÍGLER, P. - KUŽEL, S. 2002. Contribution to understanding the mechanism of titanum action in plant. In Journal of Plant Nutrition, vol. 25, pp. $577-598$.

EASTIN, E.F. 1978. Total nitrogen determination for plant material containing nitrate. In Analytical Biochemistry, vol. 85, no. 2, pp. 591-594.

EBBS, S. - UCHIL, S. 2008. Cadmium and zinc induced chlorosis in Indian mustard [Brassica juncea (L.) Czern] involves preferential loss of chlorophyll $b$. In Photosynthetica, vol. 46, no. 1, pp. 49-55.

ERCOLI, L. - MARIOTTI, M. - NICCOLAT, L. - MASONI, A. - ARDUINI. 2008. The use of titanium shavings as a fertilizer alternative for maize production. In Agrochimica, vol. LII, no. 2, pp. 1- 17.

KOVÁČIK, P. - ONDRIŠÍK, P. - KOZÁNEK, M. DVONČOVÁ, D. - FAZEKAŠOVÁ, D. 2011. Účinok prasacieho hnoja fermentovaného larvami muchy domácej na úrodu kukurice siatej a slnečnice ročnej [The effect of pig manure fermented by larvae of house flies on the yield of maize and sunflower]. In Agrochémia, vol. 51, no. 2, pp. 19-23.

KOVÁČIK, P. 2014. Principy a spôsoby výživy rastlin [The principles and ways of plant nutrition]. Nitra : SPU v Nitre. 278 pp. ISBN 978-80-552-1193-0. 
KOVÁČIK, P - BARAN, A. - FILOVÁ, A. - VICIAN, M. - HUDEC, J. 2014. Content changes of assimilative pigments in leaves after fertilizer Mg-Titanit application. In Acta fytotechnica zootechnica, vol. 17, no. 2, pp. 58-64.

KUŽEL S. - HRUBÝ M. - CÍGLER P. - TLUSTOŠ P. PHU, N.V. 2003. Mechanism of physiological effects of titanium leaf sprays on plants grown on soil. In Biology of Trace Element Research, vol. 91, pp. 179-189.

KUŽEL, S. - CÍGLER, P. - HRUBÝ, M. - VYDRA, J. PAVLÍKOVÁ, D. - TLUSTOŠ, P. 2007. The effect of simultaneous magnesium application on the biological effects of titanium. In Plant Soil Environment, vol. 53, no. 1, pp. 16-23.

LICHTENTHALER, H.K. 1987. Chllorophyll and carotenoides: Pigments of photosynthetic biomembranes. In Methods in Enzymology, vol. 148, pp. 350-382.

LOPEZ-MORENO, J.L. - GIMÉNEZ, J.L. - MORENO, A. - FUENTES, J.L. - ALCARAZ, C.F. 1996. Plant biomass and fruit yield induction by Ti(IV) in P-stressed pepper crops. In Fertilizer Research, vol. 43, pp. 131-136.

MARSCHNER, H. 2005. Mineral nutrition of higher plants. London : Elsevier Academic Press. 889 pp. ISBN 0-12-473543-6.

MATUŠKOVIČ, J. 1995. Evaluation of yield and selected quality parameters interactions of strawberry variety "Senga Sengana“ as influenced by utilization of "Titavin“ preparator. In Acta fytotechnica LI Universitatis agriculturae Nitra - Slovakia, vol. 51, pp. 105-110.
MEHLICH, A. 1984. Mehlich 3 soil test extractant: A modification of Mehlich 2 extractant. In Communication in Soil Science and Plant Analysis, vol. 15, pp. 1409-1416.

PAIS, I. 1983. The biological importance of titanium. In Journal of Plant Nutrition, vol. 6, pp. 3-131.

TLUSTOŠ, P. - CÍGLER, P. - HRUBÝ, M. - KUŽEL, S. - SZÁKOVÁ, J. - BALÍK, J. 2005. The role titanium in biomass production and its influence on essential elements' contents in field growing crops. In Plant Soil Environment, vol. 51, no. 1, pp. 19-25.

TRAETTA-MOSCA, F. 1913. Titanium and the rare metals in the ash of the leaves of Kentucky tobacco cultivated in Italy. In Gazzetta Chimica Italiana, vol. 43, pp. 437-440.

TŮMA, J. - TŮMOVÁ, L. 2006. Hořčík a jeho úloha v rostlinách [Magnesium and its role in plants 2006]. In Vliv abiotických a biotických stresorü na vlastnosti rostlin. Prague : ČZU, pp. 19-23, ISBN 80-2131484-2.

TICHÝ I. - TÓTH, J. 1990. Výsledky overovania Titavinu v cukrovej repe [Results of the verification Titavin in sugar beet plants] In Agrochémia, vol. 30, no. 8, pp. 225-229.

ZBÍRAL, J. - MALÝ, S. - VÁŇA, M. - ČUHEL, J. FOJTLOVÁ, E. - ČIŽMÁR, D. - ŽALMANOVÁ, A. SRNKOVÁ, J. - OBDRŽÁLKOVÁ, E. 2011. Jednotné pracovni postupy, Analýza půd III. [The uniform working methods, Analysis of soils] Brno : ÚKZÚZ. 230 pp. ISBN 978-80-7401-040-8.

Received: November 11, 2014 